\title{
ASSESSMENT OF NUTRITIONAL STATUS AND ITS DETERIMINANTS AMONG CHILDREN IN AGE GROUP OF 1-5 YEARS IN A TRIBAL POPULATION OF COIMBATORE DISTRICT-A CROSS SECTIONAL STUDY
}

KEY WORDS: Under-five children, Stunting, Underweight, Wasting

\section{T. Pravin}

Postgraduate, Department of Community Medicine, Rajah Muthiah Medical College Hospital, Chidambaram, Tamil Nadu.

P.I. Govindarajan*
A. John William Felix
Professor, Department of Community Medicine, Rajah Muthiah Medical College Hospital, Chidambaram, Tamil Nadu. *Corresponding Author

Reader cum Statistician, Department of Community Medicine, Rajah Muthiah Medical College Hospital, Chidambaram, Tamil Nadu.

Background: Under-five children are more vulnerable to malnutrition especially in rural areas resulting in more morbidity and mortality among them. The present study is aimed to assess the prevalence of malnutrition among children of 1-5 years of age in tribal hamlets of Valparai block, Coimbatore district in Tamil Nadu.

Methods: A community-based, cross-sectional study was conducted among 95 children in the age group of 1-5 years during December-January 2020. Anthropometric measurements were taken. The indicators of nutritional status of children like stunting, underweight, and wasting were expressed using WHO growth standards.

Results: The overall prevalence of malnutrition in our study was 31.6\%. Among the 30 (31.6\%) malnourished children, $40 \%$ were underweight, and $6.67 \%$ were severely underweight. $40 \%$ were stunted, of which $13.3 \%$ were severely stunted. Wasting was present in $23.3 \%$ of malnourished children. Severe wasting was not seen. Socio-demographic factors including the type of house, maternal education, BMI of the mother, age of mother at childbirth and place of delivery had significant association with malnutrition among under-five tribal children.

Conclusions: Malnutrition poses a serious threat to under-five children. Though many known risk factors of malnutrition have been studied, understanding the local factors linked with malnutrition is so crucial while planning information, education, and communication programs in this area.

\section{INTRODUCTION:}

An adequate well-balanced diet is highly essential for child survival, health, and development. Well-nourished children remain healthy and productive while the malnourishment stunts intellect, reduces productivity, and perpetuates poverty. It increases their susceptibility to childhood infections, such as diarrhoea, pneumonia, and malaria and thereby the under-5 mortality rate.

Undernutrition includes stunting (chronic malnutrition), wasting (acute malnutrition), and deficiencies of micronutrients (essential vitamins and minerals). Alarming rise in mortality and morbidity due to undernutrition demands urgent implementation of health schemes thereby reducing their occurrence and consequences and this would include determining action on the social determinants of undernutrition. $^{2}$

According to WHO, malnutrition is defined as a "pathological state resulting from a relative or absolute deficiency or excess of one or more essential nutrients". ${ }^{3}$

Globally, among under 5 children, 47 million are wasted, 14.3 million are severely wasted and 144 million are stunted. Around $45 \%$ of deaths among children under 5 years of age are linked to undernutrition.

NFHS 4 data shows that the proportion of malnutrition among under 5 children increases rapidly with the age from childbirth to a peak at age of 20 months. Even children who are breast fed till 6 months of age showed $20-30 \%$ of malnutrition. It is be noted that by age of 18-23 months, when weaning food is added, 30 percent are severely stunted and one-fifth are severely underweight. ${ }^{5}$

In Tamil Nadu, children's nutritional status has improved since NFHS-3 by all measures. Whatever the gains in all the nutrition indicators, child malnutrition continues to be a major problem in Tamil Nadu. ${ }^{5}$ There are small variations in the level of undernutrition by urban-rural residence or by the sex of the child. However, differences are more pronounced for other background characteristics. Malnutrition generally decreases with increasing maternal education, improved nutritional status of the mother, and a normal birth weight. Morbidity and mortality are also high among undernourished children. ${ }^{6,7}$

The prevalence of malnutrition was found to be higher in rural areas (38\%) than in urban areas $(29 \%){ }^{8,9}$

In South India, study data regarding the prevalence of malnutrition among under-five tribal-based children are limited compared with rural and urban areas. Hence this community-based study was conducted to assess the nutritional status and the association of selected known risk factors among children aged 1-5 years in the tribal hamlets of Valparai of Coimbatore.

\section{MATERIALS AND METHODS:}

Study Design : Descriptive Cross-sectional Study

Study Area : Tribal area belonging to Valparai hills of Coimbatore District,Tamil Nadu

\section{Study Population: Children aged 1-5 years}

Sample Size Determination: With an estimated prevalence of $36 \%$ from earlier studies ${ }^{5}$ and $20 \%$ allowable error, sample size was calculated as below,

$\mathrm{n}=\left(1.96^{\wedge} 2\right) \mathrm{pq} / \mathrm{d}^{\wedge} 2$

where, $n=$ Number of samples required; $p=$ Prevalence; $\mathrm{q}=100-\mathrm{p} ; \mathrm{d}=$ allowable error.

Non response rate $=20 \%$

Sample size $=91$

Study Period: Home-visits were carried out from December 2019 to January 2020.

Data Collection Tools:

Pre-tested questionnaire and physical instruments included a 
standard weighing scale, metal measuring tape.

\section{Study Protocol:}

\begin{tabular}{|c|}
\hline Coimbatore district- 4 out of 12 blocks has tribal settlements \\
\hline By random method, 1 block- Valparai was selected
\end{tabular}

9 tribal hamlets with 95 under-five children were present in the block

All 95 under-five children were included in the study (required sample size -91)

\section{Questionnaire:}

Data collection was done by interview method using a semi structured questionnaire which was pretested and modified after review in the Department. The questionnaire included socio demographic variables like age, gender, type of house, educational status of mother, BMI of mother and place of child birth. Height and weight of both the children and mother were measured using relevant instruments.

\section{Anthropometric Measurements:}

Height and weight of all the 95 children and their mothers who participated in the study were measured based on WHO recommended procedure. ${ }^{10}$

\section{Assessment Of Nutritional Status Using Anthropometry} Method:

The standard deviation score (Z-score) for weight-for-age, height-for-age and weight for-height were calculated using WHO child growth standards (2009).

(observed value) - (median reference value) Z-score (or SD-score) $=$

Standard deviation of reference population

This study adopted the cut-off points for WHO classification (Z-Scores) and broadly children are considered normal if the Z-Scores are above -2 and malnourished if Z-Scores below -2. $\mathrm{Z}$ scores less than-3SD are said to have severe malnourishment.

\section{4-HOUR FOOD RECALL METHOD:}

The total consumption of Energy and Proteins intake in terms of calories and grams was calculated using 24-hour food recall method and compared with the recommended daily allowance given by NIN. ${ }^{1}$

\section{Statistical Analysis:}

The data obtained from the study was entered in excel and analysed using 'The Anthro Survey Analyser', an online tool developed by the Department of Nutrition for Health and Development, WHO. Statistical analysis was done using SPSS 23.0 version.

\section{RESULTS:}

A total of 95 children in the age group of 1-5 years were studied out of which, 50 were boys and 45 were girls. The mean (SD) height and weight of the boys was $92.58 \mathrm{~cm}(8.81)$ and $12.86(2.22)$ respectively while the mean (SD) height and weight of girls was $91.31 \mathrm{~cm}(9.14)$ and 12.69 (2.52) respectively.
The current study showed a general prevalence of malnutrition of $32.6 \%$ while $68.4 \%$ was anthropometrically normal. Among the 30 malnourished children, 16(53.3\%) were stunted while $14(46.7 \%)$ had both underweight and wasting.

Table 1: Age Sex Distribution Of Malnourished Children:

\begin{tabular}{|l|l|l|l|l|l|l|}
\hline $\begin{array}{l}\text { Age } \\
\text { grou } \\
\mathbf{p} \\
\text { (Mo } \\
\text { nths) }\end{array}$ & $\begin{array}{l}\text { Male } \\
\text { Total } \\
\mathbf{n}(\%)\end{array}$ & $\begin{array}{l}\text { Malnou } \\
\text { rished } \\
\text { n (\%) }\end{array}$ & $\begin{array}{l}\text { Total } \\
\text { n (\%) }\end{array}$ & $\begin{array}{l}\text { Malnou } \\
\text { rished } \\
\text { n (\%) }\end{array}$ & $\begin{array}{l}\text { Total } \\
\text { n (\%) }\end{array}$ & $\begin{array}{l}\text { Malnou } \\
\text { rished n } \\
(\%)\end{array}$ \\
\hline $13-24$ & $10(20)$ & $1(10)$ & $6(13.3)$ & $1(16.7)$ & $16(16.8)$ & $2(12.5)$ \\
\hline $25-36$ & $10(20)$ & $3(30)$ & $11(24.5)$ & $7(63.6)$ & $21(22.1)$ & $10(47.6)$ \\
\hline $37-48$ & $18(36)$ & $4(22.2)$ & $11(24.5)$ & $2(18.2)$ & $29(30.5)$ & $6(20.7)$ \\
\hline $49-60$ & $12(24)$ & $5(41.7)$ & $17(37.8)$ & $7(41.2)$ & $29(30.5)$ & $12(41.4)$ \\
\hline Total & 50 & $13(26)$ & 45 & $17(37.8)$ & 95 & $30(31.6)$ \\
\hline
\end{tabular}

There is no statistically significant gender difference in the prevalence of undernutrition among different age-groups $(\mathrm{p}=.184)($ Table 1$)$

Table 2: Energy And Protein Consumption Among Children Of 1-5Years:

\begin{tabular}{|c|c|c|c|c|}
\hline \multirow{2}{*}{$\begin{array}{l}\text { RDA } \\
\text { (percentage) }\end{array}$} & \multicolumn{2}{|l|}{ Energy } & \multicolumn{2}{|l|}{ Protein } \\
\hline & $\begin{array}{l}\text { Normal } \\
\text { n (\%) }\end{array}$ & $\begin{array}{l}\text { Malnouris } \\
\text { hed n (\%) }\end{array}$ & $\begin{array}{l}\text { Normal } \\
n(\%)\end{array}$ & $\begin{array}{l}\text { Malnouris } \\
\text { hed n (\%) }\end{array}$ \\
\hline$>90$ & $5(7.7)$ & 0 & $3(4.8)$ & 0 \\
\hline $71-90$ & $38(58.5)$ & $8(26.7)$ & $11(16.9)$ & $1(3.33)$ \\
\hline $50-70$ & $22(33.8)$ & $15(50)$ & $41(63.1)$ & $15(50)$ \\
\hline$<50$ & 0 & $7(23.3)$ & $10(15.4)$ & $14(46.7)$ \\
\hline Total & 65 & 30 & 65 & 30 \\
\hline
\end{tabular}

$23.3 \%$ of malnourished children had energy consumption less than $50 \%$ RDA while $46.7 \%$ of malnourished children had less than $50 \%$ of protein consumption as shown in table 2 . There was no malnutrition found among those children who had more than $90 \%$ of energy and protein intake. Majority of the malnourished children had only $50-70 \%$ of the RDA of energy and protein.

Table 3: Nutrition Intake Associated With Malnutrition Among Under-five Children:

\begin{tabular}{|c|c|c|c|c|c|c|c|}
\hline \multirow[t]{2}{*}{$\begin{array}{l}\text { Fact } \\
\text { ors }\end{array}$} & \multirow[t]{2}{*}{\begin{tabular}{|l|} 
Cate \\
gory
\end{tabular}} & \multirow[t]{2}{*}{$\begin{array}{c}\text { Total } \\
\text { n (\%) }\end{array}$} & \multicolumn{2}{|c|}{\begin{tabular}{|l|}
$\begin{array}{l}\text { Malnour } \\
\text { ished }\end{array}$ \\
\end{tabular}} & \multirow{2}{*}{$\begin{array}{l}\text { Unadjust } \\
\text { ed odds } \\
\text { ratio }\end{array}$} & \multirow[t]{2}{*}{$\begin{array}{l}95 \% \\
\mathbf{C I} *\end{array}$} & \multirow[t]{2}{*}{$\begin{array}{l}\mathbf{P} \\
\text { value }\end{array}$} \\
\hline & & & $\mathbf{N}$ & $\%$ & & & \\
\hline \multirow{2}{*}{$\begin{array}{l}\text { Calorie } \\
\text { consum } \\
\text { ption } \\
(\% \text { of } \\
\text { RDA) }\end{array}$} & $\geq 50$ & \begin{tabular}{|l|}
86 \\
$(90.5)$
\end{tabular} & 23 & 26.7 & 1 & \multirow[t]{2}{*}{$\begin{array}{l}1.855- \\
49.542\end{array}$} & \multirow[t]{2}{*}{.002} \\
\hline & $<50$ & \begin{tabular}{|l}
9 \\
$(9.5)$
\end{tabular} & 7 & 77.8 & 9.587 & & \\
\hline \multirow{2}{*}{$\begin{array}{l}\text { Protein } \\
\text { consum } \\
\text { ption (\% } \\
\text { of RDA) }\end{array}$} & $\geq 50$ & \begin{tabular}{|l|}
71 \\
$(74.7)$ \\
\end{tabular} & 16 & 22.5 & 1 & \multirow[t]{2}{*}{$\begin{array}{l}1.799- \\
12.876\end{array}$} & \multirow[t]{2}{*}{.001} \\
\hline & $<50$ & $\begin{array}{l}24 \\
(25.3)\end{array}$ & 14 & 58.3 & 4.813 & & \\
\hline
\end{tabular}

Table 3 shows significant association of malnutrition with the nutrition intake. Calorie intake less than $50 \%$ of RDA found to be a significant risk factor with a p-value of .002 . Similarly, a protein intake of less than $50 \%$ of RDA shows nearly 5 times more risk of being malnourished. $(\mathrm{p}=.001)$

Table 4: Factors Associated With Malnutrition Among Children Of 1-5 Years:

\begin{tabular}{|c|c|c|c|c|c|c|c|}
\hline \multirow[t]{2}{*}{ Factors } & \multirow[t]{2}{*}{ Category } & \multirow[t]{2}{*}{ Total n (\%) } & \multicolumn{2}{|c|}{ Malnourished } & \multirow{2}{*}{$\begin{array}{l}\text { Unadjusted } \\
\text { odds ratio }\end{array}$} & \multirow[t]{2}{*}{$95 \% \mathrm{CI} *$} & \multirow[t]{2}{*}{ P value } \\
\hline & & & $\mathbf{N}$ & $\%$ & & & \\
\hline \multirow[t]{2}{*}{ Age of child } & $>2$ year & $79(83.2)$ & 28 & 35.4 & 1 & $.055-1.228$ & .072 \\
\hline & $\leq 2$ year & $16(16.8)$ & 2 & 12.5 & .260 & & \\
\hline \multirow[t]{2}{*}{ Sex } & Male & $50(52.6)$ & 13 & 26 & 1 & $0.242-1.386$ & .9218 \\
\hline & Female & $45(47.4)$ & 17 & 37.8 & 0.579 & & \\
\hline \multirow[t]{2}{*}{ Type of house } & Semi pucca & $87(91.6)$ & 23 & 26.4 & 1 & 2.272-16.701 & $<.001$ \\
\hline & Kutcha & $8(8.4)$ & 7 & 87.5 & 19.478 & & \\
\hline \multirow{2}{*}{$\begin{array}{l}\text { Mother's } \\
\text { Educational status }\end{array}$} & Literate & $65(68.4)$ & 11 & 16.9 & 1 & 3.164-22.724 & $<.001$ \\
\hline & Illiterate & $30(31.6)$ & 19 & 63.3 & 8.479 & & \\
\hline
\end{tabular}




\begin{tabular}{|l|l|l|l|l|l|l|l|}
\hline Mother's BMI & Normal and above & $70(73.9)$ & 16 & 22.9 & 1 & $1.633-11.296$ & .002 \\
\hline & Under weight & $25(26.32)$ & 14 & 56 & 4.295 & & \\
\hline \multirow{2}{*}{$\begin{array}{l}\text { Mothers age at child } \\
\text { birth }\end{array}$} & $\mathbf{2} 20$ & $46(48.4)$ & 9 & 42.9 & 1 & $1.226-7.755$ & .015 \\
\cline { 2 - 9 } & $<20$ & $49(51.6)$ & 21 & 19.6 & 3.083 & & \\
\hline Place of birth & Hospital/ health centre & $87(91.6)$ & 24 & & 1 & $1.486-41.747$ & .006 \\
\cline { 2 - 9 } & Home & $8(8.4)$ & 6 & & 7.874 & & \\
\hline
\end{tabular}

Table 4 shows various socio-demographic factors linked with malnutrition with the calculated unadjusted odds ratio. The risk factors including type of house, mother's education, BMI of the mother, birth factors including the age of mother at childbirth had significant association with malnutrition. Though female and higher age group children had more malnourishment, there is no significant difference among the study groups statistically ( $p>05)$.

\section{DISCUSSION:}

The study is aimed to assess the prevalence of malnutrition and their determinants among children in 1-5 years of age in the tribal hamlets of Valparai block. Of the 95 children studied, 30 were malnourished and 65 children were normal anthropometrically.

The risk factors known to be associated with malnutrition assessed in this study were age, sex, mother's education, mother's nutritional status, mother's age at pregnancy, place of delivery of the child, term of delivery of the child, birth order of the child, birth weight of the child, energy and protein consumption of the child.

\section{PREVALENCE OF MALNUTRITION:}

The child was considered to be "Malnourished" if found underweight or wasted or stunted. The general prevalence of malnutrition in our study was $31.6 \%$. Among the 30 malnourished children, $40 \%$ were underweight, and $6.67 \%$ were severely underweight. $40 \%$ were stunted of which $13.3 \%$ were severely stunted. Wasting was present in $23.3 \%$ of malnourished children. Severe wasting was not seen as calculated using WHO child growth standards. ${ }^{12,13}$ The lower levels of wasting, compared with stunting and underweight, indicate that chronic (long-term) malnutrition is more common than acute (severe but short-term) malnutrition in the study population.

As per NFHS-3 report, $54 \%$ of under 5 children were stunted, $55 \%$ underweight and $28 \%$ wasted among them. ${ }^{14}$ In the present study, the prevalence of all three indicators of malnutrition was less when compared with nationwide statistics.

Another study conducted by NIN, Hyderabad among tribal under-five children in 9 states of India in the year 2007-08 found that the overall prevalence of underweight was about $49 \%$, of which $19 \%$ were severely underweight. ${ }^{15} 51 \%$ of children were stunted, and of them, about $24 \%$ were severely stunted. About $22 \%$ had wasting, among which $7 \%$ had severe wasting.

A study conducted among 1751 children in tribal areas of Maharashtra by Meshram et al showed a higher prevalence of stunting, underweight, wasting as $61 \%, 64 \%$ and $29 \%$, than the present study. ${ }^{16}$

Rao et al conducted a study for National Institute of Research in Tribal Health (NIRTH), Jabalpur, India and concluded that $51.6 \%$ of preschool children were stunted,61.6\%were underweight, and $32.9 \%$ were wasted. ${ }^{17}$

Another study by Pradhan et al among 254 Bhil tribal children of Madhya Pradesh showed that there were 69.3\% underweight, $63.4 \%$ stunting, and $58.7 \%$ wasting. ${ }^{18}$

Bisai et al conducted study among pre-school children of Lodha tribal community of West Bengal, and found out a prevalence of $33.9 \%, 26.1 \%$ and $19.4 \%$ underweight, stunting and wasting respectively. Among these, 9.1\%, 9.7\% and 3.6\% children were having severe underweight, stunting and wasting. These findings show a slightly lower prevalence when compared to the present study. ${ }^{19}$

\section{Factors Associated With Malnutrition Among 1-5 Years Children: \\ Age Of The Child And Malnutrition:}

The present study revealed no statistically significant association between different age groups of the under-five children and malnutrition. The findings differ from study conducted by Meshram et $\mathrm{al}^{15}$ who has reported that there is an increased risk of malnutrition in older children when compared with infants, whereas the results of Bisai et al is contradictory showing more risk of malnutrition in early childhood ( $1-3$ years) when compared to older children (3-6 years).

\section{Sex Of The Child And Malnutrition:}

The present study had no significant difference in prevalence of malnutrition among male and female as per statistical analysis. Meshram et al has concluded that male under-five children are more prone for malnutrition when compared to female. $^{15}$

\section{Mother's Education And Malnutrition:}

The current study showed a significant risk of undernutrtion among children of illiterate mother. According to NFHS-4 data, a strong inverse relationship exists between maternal education and child malnutrition. ${ }^{14}$ Similarly, Meshram II et al had observed that an increased risk of malnutrition was seen among children of illiterate mothers. ${ }^{15}$ According to Islam S et al, as education level increases, risk of malnutrition decreases. ${ }^{20} \mathrm{WHO}$ report stated that children whose mothers have some primary education had 1.9 times more risk of being malnourished than that compared to children whose mothers had secondary or higher education. ${ }^{21}$

\section{Mother's Nutritional Status And Malnutrition}

The association of mother's nutritional status (BMI) with malnutrition is very much significant in the current study with an unadjusted odd's ratio of 4.295. NFHS- $3^{14}$ data and study done by Pushpa Lata Tigga and Jaydip Sen in a study done among 246 mothers in North Bengal, India indicated significant associations between mothers' and children's nutritional status. ${ }^{22}$

\section{Type Of The House (PUCCA/SEMI-PUCCA/KUTCHA) And} Malnutrition:

The study subjects were residing in semi-pucca and kutcha houses and the risk of malnutrition was observed more with poor housing conditions. A community-based nutritional assessment study done by Yadav $\mathrm{R} J$ et al showed severe and moderate levels of malnutrition to be much higher among those with poor housing conditions even with the same level of dietary intake, whereas in spite of lower dietary intake, the level of malnutrition was significantly lower among those residing in a pucca house. ${ }^{23}$

\section{Mother's Age At Child Birth And Malnutrition}

Mother who were at the age of $\leq 20$ at the time of their child birth had a significant association with malnutrition in the current study. Sonowal C J had reported that prevalence of malnourishment in children delivered by mothers before 20 years is high $(>12 \%)$ when compared to children delivered after 20 years $(<8 \%)$ in their study conducted in Maharashtra. ${ }^{24}$ 


\section{Place Of Child Birth And Malnutrition}

Home deliveries, when compared to institutional deliveries was reported as a serious association factor for malnutrition by Biswas $\mathrm{S}$ et al in a study done in West Bengal. Home delivery children had 13 times more risk of being underweight, 5 times more risk of stunting and 6 times more risk wasting than their Institutional delivery counterparts. The present study also had similar association pertaining to place of birth. ${ }^{25}$

\section{Protein Energy Intake And Malnutrition}

Consumption of $<50 \%$ of the recommended amount of calories and protein were found to be another serious risk factor for malnutrition according to the present study. Mishra et al in their study of 520 under-five children of Varanasi showed that $90 \%$ of the malnourished children were consuming $<50 \%$ of the RDA of calories and the results were consistent with the current study. ${ }^{26}$

\section{CONCLUSION:}

The present study demonstrates that all the indicators of malnutrition-stunting, underweight and wasting remain to be a considerable burden among tribal under-five children. Various socio-demographic factors including type of house, maternal education, BMI of mother, age of mother at child birth and place of delivery had significant association with malnutrition among 1-5 years of tribal children.

\section{LIMITATIONS:}

This is a cross sectional study and hence no causal relationship can be established.

\section{RECOIMIMENDATION:}

Good maternal nutrition and improved education level of the mother plays a significant role in reducing malnutrition among under-five children. The health programs should be tailored keeping in mind the local socio-demographic factors influencing the nutrition status of the child.

\section{Funding: No funding sources}

\section{Conflict Of Interest: None declared}

Ethical Approval: Ethical approval was obtained from the Institutional Ethics Committee of Rajah Muthiah Medical College and Hospital

\section{REFERENCES:}

1. https://www.unicef.org/india/what-we-do/nutrition

2. Operational Guidelines on Facility Based Management of Children with Severe Acute Malnutrition, MoHFW, Government of India, 201 1:14

3. Jelliffe DB. The assessment of nutritional status of the community, WHO Monograph. 1966:53

4. World health organization, global database on malnutrition. Available at: http://www.who.int/ nutgrowthdb/en/.Accessed on 1 April 2020

5. National Family Health Survey 4 ;PRS

6. Haq MN. Age at menarche and the related issue: A pilot study on urban school girls. Journal of Youth and Adolescence. 1984;13(6):559-67

7. Karim A, Chowdhury AKMA, Kabir M. Nutritional status and age at secondary sterility in rural Bangladesh.J Biosocial Sci. 1985; 17(4):497-502

8. Rapid Survey on Children,Ministry ofWomen and Child Development, 2013-14

9. Malnutrition in India:The National Nutrition Strategy explained: Nivedita Rao -September 8,2017

10. Deshmukh PR, Dongre AR, Gupta SS, Garg BS. Newly developedWHO growth standards; Implications for demographic surveys and child health programs. Indian J Pediatr. 2007;74;987-90.

11. Dietary Guidelines for Indians - A Manual. National Institute of Nutrition, Hyderabad;2011:89-90.

12. Physical status:The use and interpretation of anthropometry - Report ofWHO expert committee, Geneva:World Health Organization; 1995:263-308.

13. https://apps.who.int/iris/bitstream/handle/ 10665/44129/9789241598163_ eng.pdf?ua $=1$

14. National Family Health Survey (NFHS-3), 2005-06, National Report, International Institute of Population Sciences, Mumbai

15. Meshram II, Arlappa N, Balakrishna N, Rao M K, Laxmaiah A, Brahmam GN. Trends in the prevalence of undernutrition, nutrient and food intake and predictors of undernutrition among under five-year tribal children in India. Asia Pac J Clin Nutr.2012;21(4):568-76.

16. Meshram II, Arlappa N, Balakrishna N, Mallikharjuna Rao K, Laxmaiah A, Brahmam GN. Prevalence and Determinants of Undernutrition andits Trends among Pre-School Tribal Children of Maharashtra State, India.J Trop Pediatr. 2012;58(2):125-32.

17. Rao VG, Yadav R, Dolla CK, Kumar S, Bhondeley MK, Mahendra U. Under nutrition and childhood morbidities among tribal pre-school children. Indian J Med Res. 2005;122(7):43-7.

18. Pradhan S, Sharma K. Nutritional Status of Bhil Tribal Children in Madhya Pradesh, India: A Cross Sectional Study. Stud Tribes Tribals201 1;9(1):37-40

19. Bisai S, Bose K, Ghosh A. Prevalence of Undernutrition of Lodha Children Aged 1-14 Years of Paschim Medinipur District, West Bengal, India. Iranian J Pediatr.2008; 18:323-9.

20. Islam S, Mahanta T G, Sarma R and Hiranya S. Nutritional Status of under 5 Children belonging to Tribal Population Living in Riverine (Char) Areas of Dibrugarh District, Assam. Indian J Community Med.2014 Jul-Sep; 39(3): 169-174

21. World Health Organization, Turning the tide of malnutrition Responding to the challenge of the 21st century. Nutrition for Health and Development (NHD),WHO/NHD/00.7

22. Pushpa Lata Tigga and Jaydip Sen Maternal Body Mass Index Is Strongly Associated with Children -Scores for Height and BMI. Hindawi Publishing Corporation Journal of Anthropology Volume 2016, Article ID 6538235, 10 pages

23. Yadav RJ and Singh P. Nutritional status and dietary intake in tribalchildren of Bihar. Indian Pediatr 1999;36:37-42.

24. C.J. Sonowal. Factors Affecting the Nutritional Health of Tribal Childrenin Maharashtra Ethno Med;4(1);21-36 (2010)

25. Biswas S, Bose $\mathrm{K}$. Association between place of delivery and under nutrition. Nutritional Segment:2011.

26. Mishra RN, Mishra CP, Sen P, Singh TB. Nutritional Status and Dietary Intake of Pre-school Children in Urban Slums of Varanasi. Indian Journal of Community Medicine 2001April-June;26(2);90-93 